\title{
Diabetes self-management arrangements in Europe: a realist review to facilitate a project implemented in six countries
}

Antonis A Kousoulis ${ }^{1}$, Evridiki Patelarou ${ }^{1,2}$, Sue Shea ${ }^{1}$, Christina Foss ${ }^{3}$, Ingrid A Ruud Knutsen ${ }^{3}$, Elka Todorova ${ }^{4}$, Poli Roukova ${ }^{5}$, Mari Carmen Portillo ${ }^{6}$, María J Pumar-Méndez ${ }^{6}$, Agurtzane Mujika ${ }^{6}$, Anne Rogers ${ }^{7}$, Ivaylo Vassilev ${ }^{8}$, Manuel Serrano-Gil ${ }^{8}$ and Christos Lionis ${ }^{1 *}$

\begin{abstract}
Background: Self-management of long term conditions can promote quality of life whilst delivering benefits to the financing of health care systems. However, rarely are the meso-level influences, likely to be of direct relevance to these desired outcomes, systematically explored. No specific international guidelines exist suggesting the features of the most appropriate structure and organisation of health care systems within which to situate self-management approaches and practices. This review aimed to identify the quantitative literature with regard to diabetes self-management arrangements currently in place within the health care systems of six countries (The United Kingdom, The Netherlands, Norway, Spain, Bulgaria, and Greece) and explore how these are integrated into the broader health care and welfare systems in each country.

Methods: The methodology for a realist review was followed. Publications of interest dating from 2000 to 2013 were identified through appropriate MeSH terms by a systematic search in six bibliographic databases. A search diary was maintained and the studies were assessed for their quality and risk of bias.

Results: Following the multi-step search strategy, 56 studies were included in the final review (the majority from the UK) reporting design methods and findings on 21 interventions and programmes for diabetes and chronic disease self-management. Most $(11 / 21,52 \%)$ of the interventions were designed to fit within the context of primary care. The majority $(11 / 21,52 \%)$ highlighted behavioural change as an important goal. Finally, some $(5 / 21,24 \%)$ referred explicitly to Internet-based tools.

Conclusions: This review is based on results which are derived from a total of at least 5,500 individuals residing in the six participating countries. It indicates a policy shift towards patient-centred self-management of diabetes in a primary care context. The professional role of diabetes specialist nurses, the need for multidisciplinary approaches and a focus on patient education emerge as fundamental principles in the design of relevant programmes. Socio-economic circumstances are relevant to the capacity to self-manage and suggest that any gains and progress will be hard to maintain during economic austerity. This realist review should be interpreted within the wider context of a whole systems approach regarding self-care support and chronic illness management.
\end{abstract}

Keywords: Chronic disease, Diabetes mellitus, Europe, Government, Delivery of health care, Health policy, Health personnel, Self-care, Social welfare

\footnotetext{
*Correspondence: lionis@galinos.med.uoc.gr

${ }^{1}$ Clinic of Social and Family Medicine, Faculty of Medicine, University of

Crete, Voutes, P.O. Box 2208, Heraklion 71003, Greece

Full list of author information is available at the end of the article
} 


\section{Background}

According to the World Health Organization, long term conditions are illnesses of long duration and generally slow progression; they are by far the leading cause of mortality in the world [1]. Insufficiently controlled chronic conditions can lead to more rapid deterioration, complications, poor quality of life and increased use of the health care services [2]. Within this context, effective disease self-management - according to new models of chronic care [3] - can help to empower the patient and may aid in promoting a person's dignity, selfdetermination, and well-being, while at the same time, potentially achieving operational savings within health care systems through a reduction in utilisation. The latter is particularly important during a period of economic crisis where health care systems and welfare regimes are affected [4]. Currently, self-management support forms a central aspect of chronic illness management nationally and globally, although evidence of its success has mainly focused on individually-centred outcomes of behavioural change [5].

As Europe is facing unprecedented social, economic, demographic and epidemiologic transitions, the discussion on the structure and governance of health care systems is of primary importance as major influences on selfmanagement support infrastructures and processes. Long term conditions are the primary focus of interest, accounting for more than 30 million deaths per year and heavy health care utilisation [1]. Even though these are a central cause of quality of life deterioration, carefully designed self-management programmes are not systematically implemented to release some of this burden.

Public policy and the organisation of health and welfare shape to a large extent how policies such as selfmanagement are enacted in practice but are rarely taken into consideration in understanding the potential in terms of health and social outcomes [6]. Initiatives towards an enhanced implementation of diabetes self-management have been variably directed by various actors. Government policy, Non-Governmental-Organisations (NGOs), relevant professional groups, and health and non-health care sector providers, political will, decisions by regional boards responsible for providing or commissioning services, and private input all have impact as part of such initiatives and thus emerge as relevant issues of interest [7-9] .

\section{The EU-WISE Project}

The EU-WISE collaborative project (http:www.eu-wise. com) involves 6 countries including The United Kingdom, The Netherlands, Norway, Spain, Bulgaria, and Greece with the aim to produce a theoretical and methodological background of systems of support, summarise the structure and governance of health and welfare systems of the six participating countries and to describe, explain and profile the structure of personal networks of people with diabetes in different national contexts. Moreover, this project aims to describe and analyse the support mechanisms that operate on the meso-level, to survey the systems of support of people with diabetes and the networks of the organizations. Finally, the EU-WISE collaborative project aims to identify existing mechanisms involved in diabetes' management with the aim to develop and implement new strategies of engagement and support self-care.

\section{Aim and research questions}

The realist review reported here will inform the second work package of this EU project through the identification of quantitative published peer-reviewed literature with regard to diabetes self-management arrangements currently in place (within the health care systems of the different partner countries) and how these are integrated into the broader welfare systems. Within the EUWISE framework, it was agreed to explore the existing different welfare policies, systems provision, structure and reforms of partner healthcare systems and association through direct and indirect impact on the configuration of support for people with chronic illness, with a focus on those with type 2 diabetes.

This realist review aims to assess the key government objectives and direction of change in the provision of self-care and how the role of health care professionals is changing within this environment. Whilst for the purpose of this online search a number of research questions were identified, and they were in line with those raised during the formation of the research protocol, as the methodology of the realist review suggests, the purposes of the review were refined during the process of the literature search. Eventually (and primarily after the background search that gave a feel for the literature), the key themes to explore were guided by the following questions:

1. What is the content of policies directed at diabetes' self- management support over the last 10-15 years in the 6 participating countries (The United Kingdom, The Netherlands, Norway, Spain, Bulgaria, and Greece)?

2. Are there any governmental or other initiatives, arrangements, actions or interventions towards self-care adoption and behavioural change for chronic disease management in general and diabetes in particular?

3. To what extent do the current government actions are structured towards the provision of health care through behaviour change and self-care?

4. What changes in usual care and resources have been noticed during the last 10-15 years in the six participating countries, given the impact of the changing socioeconomic conditions? 
5. How have the roles of health care professionals changed in regards to diabetes management and in what ways have the configurations of the professional-patient relationships in services to influence self-management changed over the last $10-15$ years?

\section{Methods}

\section{Realist review and search strategy}

A realist review is a systematic method which has been used for assessing complex interventions, focused on identifying determinants of their impact, and evaluating or developing theories [10]. The aim of the realist review is to develop concepts and knowledge about variations in a phenomenon rather than seeking one comprehensive effect size. Furthermore, it can be used with quantitative, qualitative and multiple methods [11].

We drew on the principles of the realist review as this strategy for synthesising research aims to unpack the mechanisms of how complex programmes work in particular contexts and settings (what works for whom and in what circumstances). As first step in the design of the review, the underlying assumptions about how an intervention is meant to work and what impacts it is expected to have were identified and the relevant theoretical framework was put together [11]. To that end, a literature review to summarise the peer-reviewed published scientific literature in the field (stage 1) was followed. Relevant papers were then synthesised narratively (stage 2).

Stage 1 included identification of all material which had been published following a peer-reviewed process (original or policy articles). A search diary was maintained detailing the names of the databases that were searched, the keywords used and the search results.

For the literature search, a systematic approach was undertaken, utilising the specific keywords and criteria, as indicated below. The methodology of the realist review, that combines theoretical understanding with empirical evidence, was followed throughout [11]. The studies identified were grouped and presented in summary tables featuring the key messages of each one.

\section{Information resources - Search terms}

Publications of interest were identified by a search of the following information resources since 2000: PubMed, Scopus, Web of Science, PsycINFO, European Observatory on Health Systems and Policies, Centre for Reviews and Dissemination - Database of Abstracts and Reviews of Effects (DARE).

Various search terms were used to include both MeSH terms and other glossary databases. Guided by entry terms in $\mathrm{MeSH}$ and mapped terms in Emtree thesaurus, the main ones used were: Chronic Disease, Diabetes Mellitus,
Self Care Support, Self Care Management, Health Care System, Social Welfare, Chronic Illness Management, Chronic Illness Policy, Self Management Systems, Health Resources, Health Care Providers, Health Plan Implementation, Government Programmes, Skill-Mix. Within this context, indicatively, the electronic search strategy that was followed was constructed on the following search algorithm for Medline bibliographical database: (diabetes [Title/Abstract]) AND (self care support OR self care management) AND (health care system OR social welfare OR policy OR providers OR government $O R$ skill-mix). Advanced search options have been used to combine the terms (and their truncations) in every database.

Thereafter, reference lists were systematically searched for further relevant articles by two reviewers; finally, corresponding authors were contacted with regard to missing data. A relevant flow chart was constructed to detail the number of papers retrieved and the steps undertaken (Figure 1).

\section{Eligibility criteria}

The specific inclusion and exclusion criteria that have been proposed in the review protocol are illustrated in Table 1.

\section{Data collection and management process}

A standard 'search diary' was maintained detailing the names of the databases that were searched, the keywords used and the search results. Titles and abstracts of studies to be considered for retrieval were recorded on a form, along with details of where the reference had been found. Inclusion and exclusion decisions were recorded on a database. Retrieved studies were filed according to inclusion and exclusion decisions. Studies were selected for retrieval after two independent reviewers had appraised titles and abstracts identified in electronic searches. All references provided by expert contacts were also retrieved.

Two reviewers (AK, EP) independently abstracted data and all relevant information, which was placed onto a form and summarised in order to identify what was considered to be the most important results from each study. These summaries were compared and any differences of opinion were resolved by discussion and consultation with the original study.

\section{Data synthesis and risk of bias in individual studies}

For the narrative synthesis, the studies were grouped and presented in Summary Tables featuring key points of each study (Tables 2 and 3). A standard form was used to assist the sorting of primary source material, but in the context of the realist review a bespoke form was developed to serve a different purpose (see Table 3). Preliminary primary sources 


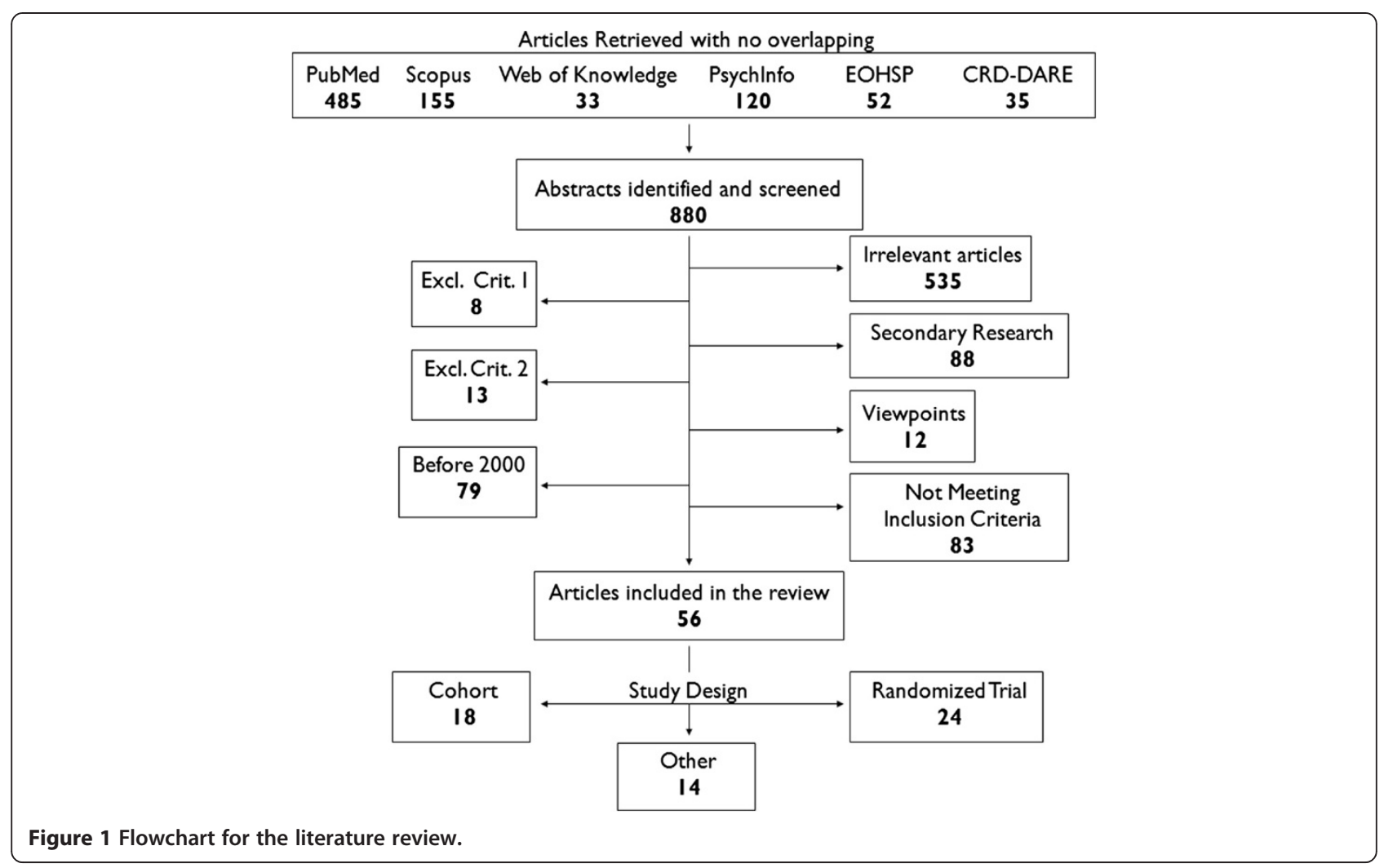

(as in the paper by Bower et al. for example [12]) were included in the results as it is important in a realist review to identify possible relevant concepts and theories [11]. Furthermore, in terms of quality appraisal and to identify fatally flawed empirical papers (which in a realist review differs from the methodological approach of a systematic review), we decided to assess the five prompts suggested by Dixon-Woods et al for all studies: (i) Are the aims and objectives of the research clearly stated? (ii) Is the research design clearly specified and appropriate for the aims and objectives of the research? (iii) Do the researchers provide a clear account of the process by which their findings were reproduced? (iv) Do the researchers display enough data to support their interpretations and conclusions? (v) Is the method of analysis appropriate and adequately explicated? [13]. The quality appraisal of the evidence occurred in parallel with the synthesis and narration of results, and judgment had to be used to supplement the formal critical appraisal checklist and consider all included articles in terms of relevance and rigour [11].

\section{Results}

Literature review

In this section the raw data results from the literature search are presented. A more elaborated presentation of the results, in the context of the realist study and its conclusions in terms of factors potentially relating to the variation in the phenomena of interest, is detailed further in the Discussion section.

The multi-step search strategy yielded 880 documents from six bibliographical databases. As a result of the evaluation, 535 articles were deemed irrelevant, 101 matched the exclusion factors, 83 did not fit the inclusion criteria as outlined in Table 1, and 106 did not constitute original research. All in all, 56 studies were included in the final review reporting design methods and findings on 21 interventions and programmes for diabetes and chronic disease self-management, since 2000 (Figure 1). Twenty-four out of the 56 studies were randomised controlled trials, 18 used a cohort design, and 14 followed other designs including cost-effectiveness analyses, complex intervention framework and presentations of programmes. The themes discussed by all were revolving around the same basic axes. Secondary research and relevant systematic reviews were only later integrated to further enhance the Discussion. Thirteen of the studies (61.9\%) came from the The United Kingdom, five (23.8\%) from The Netherlands, one (4.76\%) from Norway, one (4.76\%) from Spain, and one (4.76\%) from Bulgaria; only initial discussions and approaches have taken place in Greece [68]. Characteristics and detailed information of the included studies are listed in Table 2. Relevant productive information on the background to the introduction of the selected initiatives is included in Table 3. 


\begin{tabular}{ll}
\hline Inclusion & Exclusion \\
\hline $\begin{array}{l}\text { 1. Published articles providing information and evidence relevant } \\
\text { to the management of diabetes mellitus in health care services } \\
\text { and its integration in the broader welfare systems. }\end{array}$ & $\begin{array}{l}\text { 1. Evidence published in languages other than English (except each } \\
\text { partner specific language). }\end{array}$ \\
$\begin{array}{l}\text { 2. Published articles reporting government initiatives, actions, } \\
\text { interventions and specific country policies that promote self-care } \\
\text { adoption and behaviour change interventions in patients with } \\
\text { chronic illness. }\end{array}$ & $\begin{array}{l}\text { 2. Published articles reporting government initiatives, actions, interventions } \\
\text { and specific country policies that promote self-care adoption and behaviour } \\
\text { change interventions in patients without chronic illness. }\end{array}$ \\
$\begin{array}{l}\text { 3. Published articles reporting methods and tools used in } \\
\text { interventions that promote self-care adoption and behaviour } \\
\text { change in patients with chronic illness. }\end{array}$ \\
$\begin{array}{l}\text { 4. Published articles reporting and discussing the role of key } \\
\text { professional groups and particularly health care professionals in } \\
\text { interventions that promote self-care adoption and behaviour } \\
\text { change in patients with chronic illness. }\end{array}$ \\
\hline
\end{tabular}

Initiatives that only provided information in a didactic format or manipulated delivery of information (e.g. assessment of telephone consultations) were not included because provision of information alone has been recognised as insufficient for improved self-management [69]. Nevertheless, information and contextual aspects of these papers have been discussed. Many (11/21, 52\%) of the interventions were designed to fit within the context of general practice as the primary setting. Fifty-two per cent $(11 / 21)$ clearly stated behavioural change as an important goal, whereas the concepts of empowering patients and addressing individual responsibility were stated in the remaining $48 \%(10 / 21)$. Five interventions (24\%) referred to Internet-based tools.

The professional role of diabetes specialist nurses, the need for multidisciplinary approaches and the focus on patient education emerge as fundamental principles in the design of relevant programmes from the majority of the papers $(16 / 21,76 \%)$. The results of the current review, indicating a shift towards patient-centred self-care of diabetes, derive from a total of at least 5,500 individuals residing in the six participating countries.

\section{Discussion}

\section{What was revealed in this review?}

As evident by the review, success of self-management as a policy solution will be affected by interacting influences at three levels: [a] at micro-level by individuals' dispositions and capabilities; [b] at meso-level by roles, relationships and material conditions within the family and in the workplace, school and healthcare organisation; and [c] at macro-level by prevailing economic conditions, cultural norms and expectations, and the underpinning logic of the healthcare system [8]. Even though interventions are usually developed for specific chronic diseases, the themes and behavioural strategies are comparable across various disease-homogeneous groups of patients. All chronically ill patients face psychological demands, such as maintaining an optimal quality of life, preserving a reasonable emotional balance and sustaining relationships with family and friends [54]. Social networks, especially, seem to offer an opportunity to redress the balance of an exclusively individual focus on self-management [70], because they address the broader set of contributions and resources available to people in need of chronic illness management and support [5].

In an overview of its key findings, the literature review identifies the need for development of accessible and relevant educational material; improved communication of disease-specific information between patients and providers, as well as providers and community resources; and strategies to improve the convenience and cost of monitoring devices. However, basic diabetes education (including comprehensive programmes and training to enhance personal understanding of the disease and its implications and advance the practice of self-management) should be regarded as having broad patient-based positive outcomes, but should not be expected to have lasting benefits on glycaemic control [25]. In general, the literature indicates reservations in effects of different measures. For example, exercise consultation is more effective in stimulating exercise behaviour change in the short term than a standard exercise leaflet [71]. Educational interventions should have multiple components. They should aim to improve patients' sense of self-efficacy and empowerment [72], and develop attitudes towards diabetes that will support the lifestyle changes needed for successful self-management [73]. Interestingly, locally developed education programmes seem to have less effect than interventions developed for the purposes of research studies. This is most likely attributed to the fact that study interventions are applied in a controlled environment, strictly following guidelines and not subject to the limitations of routine practice, but long term impact should also be taken into account [58]. 
Table 2 An overview of the studies included in the review

\begin{tabular}{|c|c|c|c|c|c|c|c|c|}
\hline Country & Initiative & Relevant citations & Definition & $\begin{array}{l}\text { Goals to be } \\
\text { obtained }\end{array}$ & $\begin{array}{l}\text { Overall studies } \\
\text { participants }\end{array}$ & Main research findings & Setting & Professionals roles \\
\hline UK & $\begin{array}{l}\text { Local Diabetes } \\
\text { Centres (within } \\
\text { The Diabetic } \\
\text { Retinopathy } \\
\text { Screening Service } \\
\text { for Wales) }\end{array}$ & Dennis et al, 2000[14] & $\begin{array}{l}\text { Education, Community } \\
\text { based service, Real and } \\
\text { virtual specialist support } \\
\text { service, Enhanced all- } \\
\text { Wales screening service. }\end{array}$ & Behaviour change. & $\begin{array}{c}\text { Locally } \\
\text { implemented }\end{array}$ & $\begin{array}{l}\text { Some elements (funding, } \\
\text { structure have been } \\
\text { successful in promoting } \\
\text { self-management, but } \\
\text { some need revising } \\
\text { (education, behavioural } \\
\text { change). There are } 3 \\
\text { models of diabetes } \\
\text { education in Wales. } \\
\text { More to be invested in } \\
\text { this area in the years to } \\
\text { come. }\end{array}$ & Primary Care & $\begin{array}{l}\text { Patient education a } \\
\text { requirement of all } \\
\text { providing services to } \\
\text { patients with diabetes. } \\
\text { Staff encouraged to } \\
\text { set an example. }\end{array}$ \\
\hline UK & $\begin{array}{l}\text { DAFNE (Dose } \\
\text { Adjustment For } \\
\text { Normal Eating) }\end{array}$ & $\begin{array}{l}\text { Jack, 2001; DAFNE Study } \\
\text { Group, 2002; Shearer } \\
\text { et al, 2004; Speight et al, } \\
\text { 2010; Lawton et al, 2010; } \\
\text { Rankin et al, 2011; } \\
\text { Leelarathna et al, 2011; } \\
\text { Keen et al, 2012; Gunn } \\
\text { et al, 2012; Rankin et al, } \\
2012 \text { [15-24] }\end{array}$ & $\begin{array}{l}\text { A course teaching flexible } \\
\text { intensive insulin treatment } \\
\text { combining dietary freedom } \\
\text { and insulin adjustment } \\
\text { (delivered in } 35 \text { hours } \\
\text { over } 5 \text { consecutive days). }\end{array}$ & Dietary freedom. & 715 & $\begin{array}{l}\text { Improved quality of life } \\
(\mathrm{p}<0.001) \text { and glycaemic } \\
\text { control ( } p<0.0001) \text { in people } \\
\text { with type } 1 \text { diabetes without } \\
\text { worsening severe } \\
\text { hypoglycaemia or } \\
\text { cardiovascular risk. Has the } \\
\text { potential to be a cost-saving } \\
\text { initiative. The impact of a } \\
\text { single DAFNE course on } \\
\text { glycaemic control remains } \\
\text { apparent in the long term } \\
\text { (4 years). DAFNE delivered in } \\
\text { routine clinical practice is } \\
\text { associated with a range of } \\
\text { benefits and certain clinical } \\
\text { and psychosocial characteristics } \\
\text { are associated with better } \\
\text { outcomes. Results show } \\
\text { significant reductions in total, } \\
\text { quick acting and basal insulin } \\
\text { (all } p<0.0005) \text { doses in } \\
\text { patients undergoing } \\
\text { DAFNE training. }\end{array}$ & $\begin{array}{l}\text { Secondary } \\
\text { Care - Dia } \\
\text { betes Clinics }\end{array}$ & $\begin{array}{l}\text { Diabetes specialist } \\
\text { nurses and dieticians } \\
\text { who attended a } \\
\text { training course. }\end{array}$ \\
\hline UK & $\begin{array}{l}\text { LAY (Look After } \\
\text { Yourself programme) }\end{array}$ & $\begin{array}{l}\text { Cooper et al, 2003a; } \\
\text { Cooper et al, 2003b; } \\
\text { Cooper et al, } 2008 \\
{[25-27]}\end{array}$ & $\begin{array}{l}\text { Theoretically constructed } \\
\text { on the premise that } \\
\text { knowledge acquisition } \\
\text { alone does not necessarily } \\
\text { promote self-directed action. } \\
\text { Rather, systems of } \\
\text { motivation and the } \\
\text { teaching of skills (practical, } \\
\text { physical, conceptual, } \\
\text { emotional, social and } \\
\text { personal) are stressed. }\end{array}$ & $\begin{array}{l}\text { Behaviour change, } \\
\text { empowerment- } \\
\text { based education. }\end{array}$ & 89 & $\begin{array}{l}\text { Associated with only limited } \\
\text { benefits in glycaemic control } \\
\text { (only significant in } 6 \text { months, } \\
p<0.005) \text {, but there were } \\
\text { significant educational } \\
\text { ( } p<0.002 \text { ) and psychological } \\
\text { benefits. }\end{array}$ & $\begin{array}{l}\text { Primary Care/ } \\
\text { Hospital }\end{array}$ & $\begin{array}{l}\text { Diabetes specialist } \\
\text { nurses trained in } \\
\text { the programme. }\end{array}$ \\
\hline UK & & Cradock, 2004 [28] & & Behaviour change. & & & Primary Care & \\
\hline
\end{tabular}


Table 2 An overview of the studies included in the review (Continued)

Portsmouth Primary

Care Trust, Self-

management pro

grammes for

people with

diabetes

\section{UK UCL-DSMP}

(University College

London-Diabetes

Self Management

Programme)

UK Librae

Franklin et al, 2006 [30]

educational intervention

aimed at improving

biomedical and

Software package in the form of 'diabetes diary' (validated algorithm) to input data related to self-management.

predictive tool.

for self-management. psychosocial outcomes.

DESMOND (Diabetes Skinner et al, 2006; Education and Davies et al, 2008;

Self-Management Davies et al, 2008;

for Ongoing and

Skinner et al, 2008;

Structured education

program on illness beliefs

Newly Diagnosed)

Gillett et al, 2010;

Skinner et al, 2011;

Khunti et al, 2012

[35-41]

Locally

Engaging with patients in a group situation appears to be beneficial. The programme

has run since 2001 and the

evidence is that it is working

(3 practices added group

follow-up).

Individual

esponsibility

Educational

Behavioural change, skills and confidence

124

At immediate post-intervention and three-month follow-up

the intervention group showed

significant improvement relative

to controls on self-management

behaviours $(p<0.01)$, quality of

life $(p<0.01)$ and illness beliefs

$(p<0.05)$. A trend towards

improved $\mathrm{HbA1} 1 \mathrm{c}$ was also

observed $(p<0.01)$.

15

The modelled values of

'Librae' correlated well with

the continuous blood glucose

monitoring data (positive

mean $0.35 \mathrm{mmol} / \mathrm{L})$, but

clinically unacceptable errors

occurred at extremes of blood

glucose levels.

257 A small improvement in

patient diabetes-related

distress ( $p=0.012$ ) and

confidence to self-care over

26 weeks, but no significant

difference in $\mathrm{HbA} 1 \mathrm{c}(\mathrm{p}=0.39)$.

The programme requires close

communication and openness

towards collaborative

approaches to improve skills

and confidence for

self-management.

Behavioural change,

illness awareness,

lifestyle outcomes. 
Brief (2.5 days) psychoducational intervention programme based on theories of patient empowerment and discovery learning, to develop skills and confidence eading to increasing diabetes self-management and sustain improvement.

Armstrong et al, 2008; Internet-based selfJennings et al, 2009; Powell et al, 2009; Armstrong et al, 2012 [47-50] nagement tool for diabetes allowing patients to communicate with their health professionals, find information about their condition and share support and advice with others through peer-to-peer discussions. patterns of responding to

illness. The intervention is

likely to be cost effective

compared with usual care. A

single programme for people

with newly diagnosed type 2

diabetes showed no difference

in HbA1c $(P=0.81)$ or lifestyle

outcomes at 3 years, but

illness belief score differed

significantly $(p=0.01)$.
Personal responsibility, lifestyle and psychosocial outcomes.
191

Attendance rates 58\%.

Participation in the X-PERT

Programme by adults with

$\mathrm{T}-2 \mathrm{D}$ was shown at 14 months

to lead to improved glycaemic

control, reduced total cholesterol

level, body weight, BMI \& waist

circumference, reduced

medication, increased

consumption of fruit and

vegetables, enjoyment of

food, knowledge of diabetes,

self-empowerment,

self-management skills and

treatment satisfaction (all

self-reported).

Patient

empowerment

User-centred

approach, Support

for patients to

become effective

self-managers

Behavioural,

lifestyle change.
114

At 12 months, had no

significant impact on $\mathrm{HbA} 1 \mathrm{c}$ $(p=0.94)$ or severe

hypoglycaemia, but improved

diabetes treatment satisfaction

$(p=0.006)$ and patient

empowerment.

The pilot study did not identify evidence of an impact quality of life or self-efficacy in patients who used insulin pump therapy. Users found participation reassuring. They rated peer interaction (53\%) as the most desirable and the most useful of the features available. in reducing $\mathrm{HbA} 1 \mathrm{c}$ levels requirement for diabetes
Primary Care The programme trains health-care professionals to deliver it to people with diabetes.

Secondary Nurses and dieticians. Care Multidisciplinary teams.

Hospital Online "ask an expert" clinics (online sessions conducted community) with diabetes specialists not directly involved directly involved with the patients care. $(p=0.0004)$, blood pressure 
Table 2 An overview of the studies included in the review (Continued)

\begin{tabular}{|c|c|c|c|c|c|c|c|c|}
\hline & $\begin{array}{l}\text { care management } \\
\text { service }\end{array}$ & & $\begin{array}{l}\text { support for self-management } \\
\text { and lifestyle change) for pa } \\
\text { tients with poorly controlled } \\
\text { diabetes. }\end{array}$ & & & $\begin{array}{l}\text { and BMI in people with } \\
\text { diabetes. Study design had } \\
\text { limitations (controls matched } \\
\text { from a retrospective cohort). }\end{array}$ & & \\
\hline UK & $\begin{array}{l}\text { Whole Systems } \\
\text { Model }\end{array}$ & Bower et al, 2012 [12] & $\begin{array}{l}\text { Self-management support } \\
\text { through an evidence-based } \\
\text { 'whole systems' model } \\
\text { involving patient support, } \\
\text { training for primary care } \\
\text { teams, and service } \\
\text { re-organisation, all integrated } \\
\text { into routine delivery within } \\
\text { primary care. }\end{array}$ & $\begin{array}{l}\text { Behaviour change, } \\
\text { Whole System } \\
\text { Approach }\end{array}$ & Designed & Protocol paper only & Primary Care & $\begin{array}{l}\text { Multidisciplinary } \\
\text { approach }\end{array}$ \\
\hline Netherlands & $\begin{array}{l}\text { CBGT (Cognitive } \\
\text { Behavioural Group } \\
\text { Training) }\end{array}$ & $\begin{array}{l}\text { Snoek et al, 2001; } \\
\text { van der Ven et al, } \\
\text { 2005a; van der Ven } \\
\text { et al, 2005b [51-53] }\end{array}$ & $\begin{array}{l}4 \text { weeks cognitive behavioural } \\
\text { small group training aimed } \\
\text { at modifying dysfunctional } \\
\text { beliefs, reducing negative } \\
\text { emotions and enhancing } \\
\text { self-care practices. }\end{array}$ & Behavioural change & 131 & $\begin{array}{l}\text { Following CBGT, mean HbA1c } \\
\text { dropped by } 0.8 \% \text { at } 6 \text { months } \\
\text { from baseline }(p=0.36) \text {, while } \\
\text { emotional well-being was } \\
\text { preserved. CBGT was successful } \\
\text { in improving self-efficacy } \\
(p=0.01) \text {, diabetes-related } \\
\text { distress }(p=0.01) \text { and mood } \\
(p<0.001) \text { at } 3 \text { months' } \\
\text { follow-up, but not in } \\
\text { improving glycaemic control. }\end{array}$ & $\begin{array}{l}\text { Outpatient } \\
\text { setting }\end{array}$ & $\begin{array}{l}\text { Diabetes nurse } \\
\text { specialist and } \\
\text { psychologist. }\end{array}$ \\
\hline Netherlands & $\begin{array}{l}\text { Theory-driven } \\
\text { Intervention }\end{array}$ & $\begin{array}{l}\text { Schreurs et al, } 2003 \\
\text { [54] }\end{array}$ & $\begin{array}{l}\text { Action plans to enhance } \\
\text { self-management provided } \\
\text { to disease-homogeneous } \\
\text { groups of patients. }\end{array}$ & $\begin{array}{l}\text { Planning of } \\
\text { behaviour, } \\
\text { goal-setting }\end{array}$ & 24 & $\begin{array}{l}\text { The majority of participants } \\
\text { were satisfied with the } \\
\text { programme and positive } \\
\text { about most of the intervention } \\
\text { aspects (evaluation scores r } \\
\text { anged 3.03-4.05/5). Patients } \\
\text { of older age, lower education, } \\
\text { or no current employment } \\
\text { responded best to the } \\
\text { intervention. }\end{array}$ & $\begin{array}{l}\text { Outpatient } \\
\text { department, } \\
\text { hospital }\end{array}$ & $\begin{array}{l}\text { Specialised nurses } \\
\text { trained by cognitive } \\
\text { behavioural therapists, } \\
\text { techniques applicable } \\
\text { in the daily care. }\end{array}$ \\
\hline Netherlands & Di@alog Study & $\begin{array}{c}\text { Roek et al, } 2009 \\
\text { [55] }\end{array}$ & $\begin{array}{l}\text { Web-based self- } \\
\text { management programme } \\
\text { for insulin titration in T2DM } \\
\text { patients. }\end{array}$ & $\begin{array}{l}\text { Personal } \\
\text { responsibility, } \\
\text { glycaemic control }\end{array}$ & $\begin{array}{l}\text { Designed, } \\
248\end{array}$ & Protocol paper only & $\begin{array}{l}\text { Primary Care } \\
\text { (web based) }\end{array}$ & $\begin{array}{l}\text { General Practitioner } \\
\text { and practice nurse } \\
\text { more conscious of } \\
\text { the treatment process. }\end{array}$ \\
\hline Netherlands & Diabetes Coach & $\begin{array}{l}\text { Nijland et al, } 2011 \\
\text { [56] }\end{array}$ & $\begin{array}{l}\text { Web-based application for } \\
\text { supporting the self-care of } \\
\text { patients with type } 2 \text { diabetes. }\end{array}$ & $\begin{array}{l}\text { Empowered } \\
\text { patients }\end{array}$ & 50 & $\begin{array}{l}\text { Long diabetes duration a factor } \\
\text { for increased engagement } \\
(p=0.03) \text {. Factors influencing } \\
\text { increased use of eHealth } \\
\text { technologies: (1) avoiding } \\
\text { selective enrollment, ( } 2) \\
\text { making use of participatory } \\
\text { design methods, and ( } 3 \text { ) } \\
\text { developing push factors for } \\
\text { persistence. }\end{array}$ & $\begin{array}{l}\text { Primary Care } \\
\text { (web based) }\end{array}$ & $\begin{array}{l}\text { Multidisciplinary teams, } \\
\text { patient-nurse email } \\
\text { exchange. }\end{array}$ \\
\hline
\end{tabular}


Table 2 An overview of the studies included in the review (Continued)

\begin{tabular}{|c|c|c|c|c|c|c|c|c|}
\hline Netherlands & $\begin{array}{l}\text { DIEP.info (Diabetes } \\
\text { Interactive Education } \\
\text { Programme) }\end{array}$ & $\begin{array}{l}\text { Heinrich et al, } 2012 \\
\text { [57] }\end{array}$ & $\begin{array}{l}\text { Web-based type } 2 \text { diabetes } \\
\text { self-management education } \\
\text { programme aimed at } \\
\text { improving knowledge, } \\
\text { encouraging active patient } \\
\text { participation and providing } \\
\text { supportive self-management } \\
\text { tools. }\end{array}$ & $\begin{array}{l}\text { Knowledge } \\
\text { improvement }\end{array}$ & 674 & $\begin{array}{l}\text { The effect evaluation showed } \\
\text { a significant intervention } \\
\text { effect }(p<0.01) \text { on knowledge. } \\
\text { The user evaluation showed } \\
\text { high satisfaction with the } \\
\text { programme's content, } \\
\text { credibility and user-friendliness. } \\
\text { However, it is not fully used } \\
\text { as intended. }\end{array}$ & Web-based & $\begin{array}{l}\text { Active role and clear } \\
\text { instructions for health } \\
\text { care professionals. }\end{array}$ \\
\hline Norway & $\begin{array}{l}\text { Diabetes Self } \\
\text { Management } \\
\text { Education }\end{array}$ & $\begin{array}{l}\text { Rygg et al, 2010; } \\
\text { Rygg et al, 2012 } \\
\text { [58,59] }\end{array}$ & $\begin{array}{l}\text { Locally developed group } \\
\text { based education. }\end{array}$ & $\begin{array}{l}\text { Knowledge } \\
\text { improvement, } \\
\text { skills }\end{array}$ & 168 & $\begin{array}{l}\text { The controls in locally } \\
\text { developed ongoing diabetes } \\
\text { self-management education } \\
\text { programs prevented an } \\
\text { increase }(0.3 \%) \text { in HbA1c and } \\
\text { can have an effect in patients } \\
\text { with higher levels. Locally } \\
\text { developed education } \\
\text { programmes seem to have } \\
\text { less effect than interventions } \\
\text { developed for studies. }\end{array}$ & Hospital & $\begin{array}{l}\text { Led by diabetes nurses, } \\
\text { and input by physician, } \\
\text { physiotherapist and a } \\
\text { lay person. }\end{array}$ \\
\hline Spain & eHealth platform & $\begin{array}{l}\text { Fico et al, 2011; } \\
\text { Fioravanti et al, } \\
2011[60,61]\end{array}$ & $\begin{array}{l}\text { Technological platform for } \\
\text { diabetes disease } \\
\text { management. }\end{array}$ & $\begin{array}{l}\text { Web usability to } \\
\text { induce self-care }\end{array}$ & 23 & $\begin{array}{l}\text { High usability and satisfaction } \\
\text { (score } 4.7 / 6) \text {. }\end{array}$ & Web-based & $\begin{array}{l}\text { Clinicians, market } \\
\text { analysis and } \\
\text { technology experts. }\end{array}$ \\
\hline Bulgaria & $\begin{array}{l}\text { DEPB (Diabetes } \\
\text { Education Program } \\
\text { in Bulgaria) }\end{array}$ & DEBM, 2001[7] & $\begin{array}{l}\text { A large-scale unified } \\
\text { structured educational } \\
\text { programme for insulin- } \\
\text { treated diabetic patients. }\end{array}$ & $\begin{array}{l}\text { Education, } \\
\text { knowledge } \\
\text { improvement, } \\
\text { empowered } \\
\text { patients }\end{array}$ & 1037 & $\begin{array}{l}56 \text { educational centres. } \\
\text { Trained patients cope better } \\
\text { with their condition. }\end{array}$ & $\begin{array}{l}\text { Regional } \\
\text { centers } \\
\text { (potential } \\
\text { for primary } \\
\text { care) }\end{array}$ & Endocrinologist, nurse. \\
\hline
\end{tabular}


Table 3 Background on the implementation of the selected initiatives

\begin{tabular}{|c|c|c|}
\hline Initiative & Country & Background information \\
\hline Diabetic Retinopathy Screening & UK & Political commitment to an all-Wales screening service $[14,62]$. \\
\hline DAFNE & UK & $\begin{array}{l}\text { Multicentre trial under Diabetes UK, based on programme developed } \\
\text { by a German group }[15,17] \text {. }\end{array}$ \\
\hline LAY & UK & $\begin{array}{l}\text { The philosophy and push came from the Long Term Condition Alliance. } \\
\text { Signed up to the US scheme of LTCM }[25,63,64] \text {. }\end{array}$ \\
\hline Portsmouth Primary Care Trust & UK & $\begin{array}{l}\text { Started outside governmental knowledge on EPP, in collaboration with } \\
\text { Portsmouth Hospitals NHS Trust [28]. }\end{array}$ \\
\hline UCL-DSMP & UK & University-run trial [29]. \\
\hline Librae & UK & Model with the intention to enter routine clinical practice [30]. \\
\hline Diabetes Manual & UK & University-developed package [32,65]. \\
\hline DESMOND & UK & $\begin{array}{l}\text { Collaborative of NHS organisations, co-ordinating centre hosted by University } \\
\text { Hospitals of Leicester NHS Trust }[41,66] \text {. }\end{array}$ \\
\hline X-PERT & UK & Variant on the DESMOND programme, local factors implicated [44]. \\
\hline BITES & UK & Variant on the DAFNE programme, university funded [45]. \\
\hline Diabetes Virtual Clinic & UK & Pilot study, internally university funded $[48,50]$. \\
\hline Birmingham Own Health & UK & $\begin{array}{l}\text { Sponsored in part by the private sector in a mixed model of health } \\
\text { economy }[2,67] \text {. }\end{array}$ \\
\hline Whole Systems Model & UK & $\begin{array}{l}\text { WISE, funded by National Institute for Health Research and National Primary } \\
\text { Care Research and Development centre [12]. }\end{array}$ \\
\hline CBGT & Netherlands & Study funded by pharmaceutical funding [52]. \\
\hline Theory-driven Intervention & Netherlands & Intervention developed locally. Philosophy came from US scheme [54,64]. \\
\hline Di@log & Netherlands & Trial funded by pharmaceutical funding [55]. \\
\hline Diabetes Coach & Netherlands & $\begin{array}{l}\text { Study supported by local primary healthcare foundation and home care } \\
\text { organisation [56]. }\end{array}$ \\
\hline DIEP.info & Netherlands & University-run local programme [57]. \\
\hline Diabetes Self-Management Education & Norway & Supported by state-owned authorities [59]. \\
\hline eHealth & Spain & $\begin{array}{l}\text { Partially funded by the European Commission, under the 7th Framework } \\
\text { Programme [60]. }\end{array}$ \\
\hline DEPB & Bulgaria & Implemented by the Ministry of Health of Bulgaria [7]. \\
\hline
\end{tabular}

It has become explicit in this review that self-management of diabetes mellitus is physically, intellectually, emotionally and socially demanding. Thus, it will be expected for some patients not to engage with self-management due to personal resources (e.g. health literacy, resilience) or overwhelming personal, family and social circumstances.

\section{Socioeconomic factors, economic crisis and their impact on self-management}

Self-management of type 2 diabetes is referred to in the literature as being strongly interrelated with contextual factors [74]. Research indicates that immigrants might perceive the causes of type 2 diabetes differently compared to people of European origin. An English study [75] found that patients of European origin tend to blame themselves for developing diabetes. In contrast, patients with Pakistani and Indian backgrounds have more varied accounts to explain their diabetes onset, emerging from a more fatalistic sentiment explained as 'God's will' or genetic tendencies, or as "a thread in the fabric of life" often with a strong focus on external stress factors. An opposite perspective to selfblame is seen in accounts from white diabetes patients who externalize the responsibility for the disease. These are primarily cultural issues, but tend to be provoked by economic influences and most notably, poverty [76]. Thus, they are key issues quite visible and of relevance to the capacity to self manage in countries that have been affected by the economic crisis, including Greece, Spain and Bulgaria [77].

Socioeconomic factors impact on the experience of tension, stress and moral dilemmas in patients struggling with their self-management experience in their encounter with health professionals, even to the extent that health care workers in some cases are perceived as adding to the burden of living with a chronic disease [78]. Whilst, the literature identified few studies explicitly seeking data to illuminate the experiences of patients belonging to either socially or economically deprived groups (the concept of deprivation in this review was considered following the WHO guidelines for Europe [79,80]) both patients and 
health professionals indicate that lack of social, personal and economical resources are tightly interconnected and affect patients' self-management. In cases where there is a large social distance between patient and GP's and other health care workers this might hinder the health professional's capacity to fully engage with patients' problems [78]. Recent evidence suggests that lower social class and presumptions of being able to participate are also implicated in chronic conditions overall though this has not been looked at in relation to type 2 Diabetes [81].

These socioeconomic facts might impact further on the tensions and moral dilemmas that patients experience in their efforts to self-manage, and thus add to the burden of having a chronic disease. The literature illuminates patients' vast experience of the magnitude of economic strain experienced when living with chronic illnesses. There are certain reports from Greece where the impact of economic crisis on the quality and provision of primary care and health care services is high [82]. The economic burden of living with a chronic illness is described by patients as considerable. It affects not only ability to afford essential treatment and medication but also the ability to maintain a healthy lifestyle and quality of life. This burden does not seem to be fully acknowledged by health professionals nor by health politicians. Descriptions of economic burdens will be even more seriously impacted by the global economic downturn.

\section{Structures and resources in regards to diabetes self-management approaches}

Not unexpectedly, there is a variation of health care systems across the participating countries, different funding models and payment systems with General Practitioners (GP's) as gate keepers in some of them (England, The Netherlands, Bulgaria, Norway), and various governance schemes (primary care trusts in UK, NHS in Bulgaria and Spain, Municipalities in Norway); all seem to have an impact on the management of long term conditions.

Table 3 provides the background for the governance of self-care programmes in the participating countries, as well as the resources that have been allocated to this section. Political commitment and government initiatives have supported many of these approaches. A few of them have been designed for nationwide implementation with regional organisation.

However, certain barriers to change, most probably originating from the health care system structure, seem to exist in a number of countries (vaguely illustrated in the countries that yielded the fewest results in this review: Greece, Bulgaria, Spain and Norway) when discussing how governance and health system organisation promote or inhibit the provision of chronic illness self-management. It should be expected that national health care systems, especially at times when limited resources are available, operate targeted to cost-cutting and identification of effective alternatives.

Within this context, out of the pool of the six participating countries, the majority of research comes from The United Kingdom. The emphasis of care in the UK has now changed from being predominantly reactive to a more preventive management approach, aiming to reduce emergency hospital admissions and encourage patients to make healthier choices about diet, physical activity and lifestyle through self-management of their condition [2]. Despite the long-accepted importance of patient education in diabetes mellitus, an authoritative UK report in 2000 exposed severe deficits in patient education services, describing them as incomplete and not based on current research evidence [83]. As such, self-management interventions have been recognized as a key part of care in the National Service Framework (NSF) in the UK since 2002, spanning the decade studied in this report [84]. Until recently, however, few centres in the UK have offered self-management programmes and rarely were these evidence-based or replicable [29]. In spite of diabetes education offered to all newly diagnosed patients, no universal programme is used. However, the Diabetes Education and Self Management for Ongoing and Newly diagnosed (DESMOND) and Dose Adjustment for Normal Eating (DAFNE) programmes are fairly widely available $[25,85]$.

In The Netherlands, many Internet-based programmes have been designed, since the most frequently reported self-tests are those for diabetes [86]. In Norway, research on the use of technology, in order to enhance patients' experience, has been undertaken $[87,88]$. Further, there are programmes for patient education located in hospitals [89]. Even though it seems that usage of IT is also the trend in Spain and Greece $[60,68]$, a literature review has suggested that, despite its potential effect, the use of technology to enhance diabetes self-management is still early in its evolution [90]. The Eurozone economic crisis comes to pose further barriers in the countries that face these limitations, as studies have highlighted the impact of low income status on an effective diabetes self-management [91].

In Bulgaria, a Diabetes Education Program was designed in 1997 to introduce a large-scale unified structured educational program for insulin-treated diabetic patients. Fifty-six in-patient training centers for people with diabetes were established which are still active in all larger cities of the country, while within the required visits to an endocrinologist (which is twice yearly mandatory for patients with diabetes) 25 minutes are devoted to patient education in self-management, under the National Regulation and Instruction [7]. Informational and screening programmes for high-risk population groups are also organized for people with diabetes in Bulgaria [92]. 


\section{Organisational structure}

Since 2008, there has been an ongoing, global economic recession and a changing European shift towards a demand for cost-effective health policy. It has been an objective to explore the potential impact on the nature and direction of change in health care systems, particularly in relation to chronic illness management. Within this perspective, UK consensus guidelines recommend limited use of self-monitoring of blood glucose (SMBG) in patients with type 2 diabetes using diet and exercise, metformin and/or a glitazone. The study estimates that the potential savings of up to 17 million pound sterling could be made each year if guidelines were followed more closely. There is a need for further research into SMBG use in patients with type 2 diabetes [93]. Moreover, despite effective selfmanagement of diabetes requiring considerable behavioural change and continuous support from health professionals which can be expensive, information technology has the potential to offer cost-effective patient support, but Internet use mostly relies on the active seeking of information [94]. Several implemented initiatives have proven to be costeffective in their initial operation [66]. However, programmes using the cognitive behavioural approach may be relatively costly when delivered by specialised nurses who have to be trained by behavioural therapists [54].

Expanding on the above concepts, an apparent trend is the delivery of group self-management education. These group-based programmes, delivered in multiple sessions, can assist in the achievement of meaningful changes. Undeniably, as the aforementioned evidence mainly from The Netherlands and the UK indicate, both governmental and various organisations' initiatives target modern IT services and web-based applications [28,29,51,54]. IT is a way forward to achieve long-term continuous long term self-management support and this trend should definitely be seriously taken into account for the empowerment of new generations of patients, while exploring how to promote community participatory medicine by public institutions and build social capital engaging inter-organisational interactions.

\section{Shifting sectors and involved professionals}

The literature review clearly illustrates a shift in the management of chronic diseases from secondary to primary care that poses stakeholders with new challenges, while the fundamental role of primary care in the management of chronic diseases has been focused on policymakers and politicians in the European Union.

Structural, organisational and socio-economic influences are relevant both to the capacity of patients to self manage and policy and governments and other agencies to support progress in this field. The identification of the importance of socio-economic influences suggest that the gains to date and further progress are likely to be hard to maintain in countries impacted upon most by economic austerity and high levels of poverty and low incomes. Revision of professional roles in multi-disciplinary clinical teamwork in primary care is advocated by European governments. Nurses, GPs, dieticians, psychologists, market analysts and technology experts should collaborate to design or implement specific self-management interventions [12,45,56]. However, patients still express fragmentation and lack of coordination and often receive inconsistent and contradictory advice [95]. Certainly, not only patients, but also health care workers in primary care describe lack of communication and collaboration between healthcare professionals. Health professionals relate this lack of cooperation to general challenges of multidisciplinary work, lack of time and burden of administrative work [96]. Both GPs and nurses with a specialist education (diabetic nurse) are described as having a key role in the management of patient with long term conditions, but patients as well as professionals describe issues in inter-professional cooperations between them [96,97].

Practice nurses play an important role in the nurse-led, shared care which aims to encourage chronically ill people to participate actively in the management of their disease in selecting the organisations and interventions for care [98]. In addition, those that are trained as Diabetes Specialist Nurses not only teach and advise people with diabetes, but also modify and monitor self-management strategies and help develop shared goals, action plans, and skills [99]. Indicatively, in the UK and The Netherlands nurses have enhanced roles and some are trained in empowerment, counselling and communication skills [28,98], in Greece, it is known that nursing staff in public health care operate within a restricted and task-oriented framework and their educational preparation has little effect in practice role variations and professional needs and this may also be the case for other countries [100]. In the cultural context of these countries, where family coherence is important and can become the thorax to resist challenging situations, family caregivers can play a significant role in sharing and supporting the self-management activities of people with Type 2 diabetes [99].

GP's should perhaps take responsibility for coordinating these initiatives, reviewing guidelines and safeguarding participation $[14,55]$. In addition, findings suggest that although GP's express the view that they value the increasing patient involvement and the focus on selfmanagement, it is not always prioritized as it clashes with time constraint [101]. GP's have been found to report that their frustration with patients' non adherence has resorted to them implementing tactics of "shocking" their patients by using threats as they feel they have no other therapeutic options with which to engage patients [102]. 


\section{Usual care pathways}

In order for the much desirable behavioural change to be achieved, consistent and long-term education and constant access to relevant information is needed [103,104]. For example, recent meta-analysis identified that behavioural interventions increased free-living exercise and produced clinically significant improvements in long-term glucose control [105]. These features can be better sustained in the setting of primary care.

Interestingly, over half of the studied initiatives (52\%, $\mathrm{N}=11 / 21$ ) have been designed to operate within a primary care framework. Genuine and enduring change requires a multilevel approach, ideally integrated into routine delivery within primary care [12]. Thus, health care services are needed that are better aligned to patient practices of self-management. The above, not unexpectedly, raises the issue of the health care professional-patient relationship and underlines that both university education and continuous medical education can be enhanced with this concept. Various points within the articles included in this review highlight the influence of the setting (especially primary care) as a key determinant in the adoption of selfmanagement behaviours. As the international discussion on health care continues, especially intertwining among the herein participating countries [106-109], each government, along with local organisations, can both learn and extrapolate meaningful lessons to this end. This interaction between health care professionals and patients renders a proper undergraduate education that is not the case for all the European countries.

\section{Behavioural support}

In general, the review revealed that it is still unknown how the gender and education of patients interrelate and affect self-management and the encounter with health care practitioners. In addition, individuals' perception of social support has received less attention from researchers. In other words; there is a lack of research adapting what might be described as a biopsychosocial approach [110], or a contextual approach [76] or a partnership approach [111] to explore the way people cope with conflicting demands and economic hardship in their striving to achieve balance between managing chronic illness and living a normal life. For example, patients with long term conditions all describe their immediate and extended family as sources of not only emotional, but also practical support [112]. Family support is especially important [113], as the need for practical support related to everyday challenges is described as frequently being ignored by healthcare practitioners [114].

Within the six participating countries, there is evidence that certain actions either as laws, initiatives or programmes have been undertaken. Thus, different management programmes serve actually the same end; specific support for patients with DM in the UK (with Diabetes Education, self-monitoring for Ongoing and Newly Diagnosed, and Dose Adjustment for Normal Eating), the National Framework and contract for patients with DM in Bulgaria, and the telemedicine and technology communication in Norway, The Netherlands and Spain.

\section{Limitations}

Intensive efforts were made to elaborate on the different aspects explored in the review that primarily conveys messages to the countries that have a benefit from this FP7 project. Nevertheless, limitations of this paper should be declared. Realist reviews embrace complexity and the amount of information is sometimes hard to follow. We have attempted to make the extrapolated information more explicit by presenting the findings in different contexts in the Results and Discussion sections. Moreover, a realist review (that incorporates judgment in the interpretation and presentation) is not necessarily standardisable or reproducible in the same sense as a conventional Cochrane review [11]. Of note, while aiming at producing meaningful results at a multinational level, limited availability of studies from certain countries led to the overrepresentation of results from others, especially, The United Kingdom and The Netherlands. Based on the strict systematic method and quality appraisal of included articles, every effort was made not to omit published papers as well as to eliminate bias. Finally, recognising that social interventions are complex and that reproduction of their directions may be difficult is important. Therefore, a meaningful objective is to gather experience and identify what types of interventions work for what kinds of subjects and in which situations.

\section{Conclusion}

The governance literature review, whose results derive from a total of 56 published papers, at least 5,500 individuals residing in the six participating countries, indicates a shift towards patient-centred self-care of diabetes. They identify the need for: development of accessible and relevant education material; improved communication of disease-specific information between patients and providers, as well as providers and community resources; strategies to improve the convenience and cost of monitoring devices; cost-effective designing; and multidisciplinarity in the health care professionals' approach. Certainly, this work involves multitasking that requires assignment either to national governance bodies and health policy makers or to people accountable for the university training or, lastly, to health care providers themselves.

As demonstrated in this study, a realist review learns from real-world phenomena such as diversity, change, idiosyncrasy, adaptation and programme failure, ad it only leads to tentative recommendations [11]. Thus, this article 
should be interpreted within the wider context of the whole system approach regarding self-care support and chronic illness management and within the framework of this FP7 project. It is to be complemented with evidence on broader welfare systems and economies of partner countries along with current initiatives and community services. However, there are key messages to all participating countries and especially to those countries affected by the economic crisis. These can assist the pilot intervention that could be designed in the framework of this EU project.

\section{Competing interests}

The authors declare that they have no competing interests.

\section{Authors' contributions}

$\mathrm{CL}$ and $\mathrm{AR}$ conceived and coordinated the study. All authors (AK, EP, SS, CF, IK, ET, PR, MCP, MPM, AM, AR, VI, MSG, CL) participated in the design of the study. AK, EP, SS and CL drafted the manuscript. All authors participated in the revising and editing of the manuscript. All authors read and approved the final manuscript.

\section{Acknowledgments}

The authors acknowledge the contribution of Dr. Natalie Armstrong for sending material relevant to her publications, and the support of Rosemarie Harris, service director, and Terry Dennis, manager, in providing insight about the Diabetic Retinopathy Screening Service for Wales.

\section{Author details}

${ }^{1}$ Clinic of Social and Family Medicine, Faculty of Medicine, University of Crete, Voutes, P.O. Box 2208, Heraklion 71003, Greece. ${ }^{2}$ Florence Nightingale School of Nursing and Midwifery, King's College London, London, UK. ${ }^{3}$ Institute of Health and Society, University of Oslo, Oslo, Norway. ${ }^{4}$ Department of Economic Sociology, University of National and World Economy, Sofia, Bulgaria. ${ }^{5} \mathrm{NIGGG}$, Bulgarian Academy of Sciences, Sofia, Bulgaria. ${ }^{6}$ School of Nursing, University of Navarra, Pamplona, Spain. ${ }^{7} \mathrm{NIHR}$ CLAHRC Wessex, Health Sciences, University of Southampton, Hampshire, UK.

${ }^{8}$ Fundación Educación Salud y Sociedad, Murcia, Spain.

Received: 27 February 2014 Accepted: 11 September 2014 Published: 2 October 2014

\section{References}

1. WHO: Noncommunicable Diseases Country Profiles 2011: WHO Global Report. Geneva: World Health Organization; 2011.

2. Jordan RE, Lancashire RJ, Adab P: An evaluation of Birmingham Own Health telephone care management service among patients with poorly controlled diabetes. A retrospective comparison with the General Practice Research Database. BMC Public Health 2011, 11:707.

3. Bodenheimer T, Wagner EH, Grumbach K: Improving primary care for patients with chronic illness. JAMA 2002, 288:1775-1779.

4. Kousoulis AA, Angelopoulou KE, Lionis C: Exploring health care reform in a changing Europe: lessons from Greece. Eur J Gen Pract 2013, 19:194-199.

5. Vassilev I, Rogers A, Blickem C, Brooks H, Kapadia D, Kennedy A, Sanders C, Kirk S, Reeves D: Social networks, the 'work' and work force of chronic illness self-management: a survey analysis of personal communities. PLOS One 2013, 8:e59723.

6. McDonald R: Market reforms in English primary medical care: medicine, habitus and the public sphere. Sociol Health IIIn 2009, 31:659-672.

7. Diabetes Education Program in Bulgaria (DEPB) Project Group: Diabetes education program in Bulgaria. Patient Educ Couns 2001, 43:111-114.

8. Hinder $\mathrm{S}$, Greenhalgh T: "This does my head in". Ethnographic study of selfmanagement by people with diabetes. BMC Health Serv Res 2012, 12:83.

9. Hirsch IB, Amiel SA, Blumer IR, Bode BW, Edelman SV, Seley JJ, Verderese CA, Kilpatrick ES: Using multiple measures of glycemia to support individualized diabetes management: recommendations for clinicians, patients, and payers. Diabetes Technol Ther 2012, 14:973-983.
10. Vassilev I, Rogers A, Sanders C, Kennedy A, Blickem C, Protheroe J, Bower P, Kirk S, Chew-Graham C, Morris R: Social networks, social capital and chronic illness self-management: a realist review. Chronic IIIn 2011, 7:60-86.

11. Pawson R, Greenhalgh T, Harvey G, Walshe K: Realist review-a new method of systematic review designed for complex policy interventions. $J$ Health Serv Res Policy 2005, 10(Suppl 1):21-34.

12. Bower $P$, Kennedy $A$, Reeves $D$, Rogers A, Blakeman $T$, Chew-Graham $C$, Bowen R, Eden M, Gardner C, Hann M, Lee V, Morris R, Protheroe J, Richardson G, Sanders C, Swallow A, Thompson D: A cluster randomised controlled trial of the clinical and cost-effectiveness of a 'whole systems' model of self-management support for the management of long- term conditions in primary care: trial protocol. Implement Sci 2012, 7:7.

13. Dixon-Woods M, Cavers D, Agarwal S, Annandale E, Arthur A, Harvey J, Hsu R, Katbamna S, Olsen R, Smith L, Dixon-Woods M, Cavers D, Agarwal S, Annandale E, Arthur A, Harvey J, Hsu R, Katbamna S, Olsen R, Smith L, Riley $R$, Sutton AJ: Conducting a critical interpretive synthesis of the literature on access to healthcare by vulnerable groups. BMC Med Res Methodol 2006, 6:35.

14. Dennis T, Owens D: Transforming local care. J Telemed Telecare 2000, 6(Suppl 1):S102-S103.

15. DAFNE Study Group: Training in flexible, intensive insulin management to enable dietary freedom in people with type 1 diabetes: dose adjustment for normal eating (DAFNE) randomised controlled trial. BMJ 2002, 325:746.

16. Gunn D, Mansell P: Glycaemic control and weight 7 years after Dose Adjustment For Normal Eating (DAFNE) structured education in Type 1 diabetes. Diabet Med 2012, 29:807-812.

17. Jack D: DAFNE-controlling diabetes the German way. Lancet 2001 357:1185.

18. Keen AJ, Duncan E, McKillop-Smith A, Evans ND, Gold AE: Dose Adjustment for Normal Eating (DAFNE) in routine clinical practice: who benefits? Diabet Med 2012, 29:670-676.

19. Lawton J, Rankin D: How do structured education programmes work? An ethnographic investigation of the dose adjustment for normal eating (DAFNE) programme for type 1 diabetes patients in the UK. Soc Sci Med 2010, 71:486-493.

20. Leelarathna L, Ward C, Davenport K, Donald S, Housden A, Finucane FM, Evans M: Reduced insulin requirements during participation in the DAFNE (dose adjustment for normal eating) structured education programme. Diabetes Res Clin Pract 2011, 92:e34-e36.

21. Rankin D, Cooke DD, Clark M, Heller S, Elliott J, Lawton J: How and why do patients with Type 1 diabetes sustain their use of flexible intensive insulin therapy? A qualitative longitudinal investigation of patients' self-management practices following attendance at a Dose Adjustment for Normal Eating (DAFNE) course. Diabet Med 2011, 28:532-538.

22. Rankin D, Cooke DD, Heller S, Elliott J, Amiel S, Lawton J: Experiences of using blood glucose targets when following an intensive insulin regimen: a qualitative longitudinal investigation involving patients with Type 1 diabetes. Diabet Med 2012, 29:1079-1084.

23. Shearer A, Bagust A, Sanderson D, Heller S, Roberts S: Cost-effectiveness of flexible intensive insulin management to enable dietary freedom in people with Type 1 diabetes in the UK. Diabet Med 2004, 21:460-467.

24. Speight J, Amiel SA, Bradley C, Heller S, Oliver L, Roberts S, Rogers H, Taylor C, Thompson G: Long-term biomedical and psychosocial outcomes following DAFNE (Dose Adjustment For Normal Eating) structured education to promote intensive insulin therapy in adults with sub-optimally controlled Type 1 diabetes. Diabetes Res Clin Pract 2010, 89:22-29.

25. Cooper H, Booth K, Gill G: A trial of empowerment-based education in type 2 diabetes-global rather than glycaemic benefits. Diabetes Res Clin Pract 2008, 82:165-171.

26. Cooper H, Booth K, Gill G: Using combined research methods for exploring diabetes patient education. Patient Educ Couns 2003, 51:45-52.

27. Cooper HC, Booth K, Gill G: Patients' perspectives on diabetes health care education. Health Educ Res 2003, 18:191-206.

28. Cradock S: Helping patients to improve self management of diabetes. Heart 2004, 90(Suppl 4):iv36-iv38. discussion iv39-40.

29. Steed L, Lankester J, Barnard M, Earle K, Hurel S, Newman S: Evaluation of the UCL diabetes self-management programme (UCL-DSMP): a randomized controlled trial. J Health Psychol 2005, 10:261-276. 
30. Franklin VL, Wilson AW, Butler RA, Greene SA: A predictive tool for the self-management of diabetes (Librae): evaluation using a continuous glucose monitoring system. Diabet Med 2006, 23:21-25.

31. Lindenmeyer A, Whitlock S, Sturt J, Griffiths F: Patient engagement with a diabetes self-management intervention. Chronic IIIn 2010, 6:306-316.

32. Sturt J, Hearnshaw H, Farmer A, Dale J, Eldridge S: The Diabetes Manual trial protocol - a cluster randomized controlled trial of a selfmanagement intervention for type 2 diabetes [ISRCTN06315411]. BMC Fam Pract 2006, 7:45.

33. Sturt J, Taylor H, Docherty A, Dale J, Louise T: A psychological approach to providing self-management education for people with type 2 diabetes: the Diabetes Manual. BMC Fam Pract 2006, 7:70.

34. Sturt JA, Whitlock S, Fox C, Hearnshaw H, Farmer AJ, Wakelin M, Eldridge S, Griffiths F, Dale J: Effects of the Diabetes Manual 1:1 structured education in primary care. Diabet Med 2008, 25:722-731.

35. Davies MJ, Heller S, Skinner TC, Campbell MJ, Carey ME, Cradock S, Dallosso HM, Daly H, Doherty Y, Eaton S, Davies MJ, Heller S, Skinner TC, Campbell MJ, Carey ME, Cradock S, Dallosso HM, Daly H, Doherty Y, Eaton S, Fox C, Oliver L, Rantell K, Rayman G, Khunti K, Diabetes Education and Self Management for Ongoing and Newly Diagnosed Collaborative: Effectiveness of the diabetes education and self management for ongoing and newly diagnosed (DESMOND) programme for people with newly diagnosed type 2 diabetes: cluster randomised controlled trial. BMJ 2008, 336:491-495.

36. Gillett M, Dallosso HM, Dixon S, Brennan A, Carey ME, Campbell MJ, Heller S, Khunti K, Skinner TC, Davies MJ: Delivering the diabetes education and self management for ongoing and newly diagnosed (DESMOND) programme for people with newly diagnosed type 2 diabetes: cost effectiveness analysis. BMJ 2010, 341:C4093.

37. Khunti K, Gray LJ, Skinner T, Carey ME, Realf K, Dallosso H, Fisher H, Campbell M, Heller S, Davies MJ: Effectiveness of a diabetes education and self management programme (DESMOND) for people with newly diagnosed type 2 diabetes mellitus: three year follow-up of a cluster randomised controlled trial in primary care. BMJ 2012, 344:e2333.

38. Ockleford E, Shaw RL, Willars J, Dixon-Woods M: Education and selfmanagement for people newly diagnosed with type 2 diabetes: a qualitative study of patients' views. Chronic IIIn 2008, 4:28-37.

39. Skinner TC, Carey ME, Cradock S, Dallosso HM, Daly H, Davies MJ, Doherty Y, Heller S, Khunti K, Oliver L: 'Educator talk' and patient change: some insights from the DESMOND (Diabetes Education and Self Management for Ongoing and Newly Diagnosed) randomized controlled trial. Diabet Med 2008, 25:1117-1120

40. Skinner TC, Carey ME, Cradock S, Dallosso HM, Daly H, Davies MJ, Doherty Y, Heller S, Khunti K, Oliver L: Comparison of illness representations dimensions and illness representation clusters in predicting outcomes in the first year following diagnosis of type 2 diabetes: results from the DESMOND trial. Psychol Health 2011, 26:321-335.

41. Skinner TC, Carey ME, Cradock S, Daly H, Davies MJ, Doherty Y, Heller S, Khunti K, Oliver L: Diabetes Education and Self-Management for Ongoing and Newly Diagnosed (DESMOND): process modelling of pilot study. Patient Educ Couns 2006, 64:369-377.

42. Choudhury SM, Brophy S, Fareedi MA, Zaman B, Ahmed P, Williams R: Examining the effectiveness of a peer-led education programme for Type 2 diabetes and cardiovascular disease in a Bangladeshi population. Diabet Med 2009, 26:40-44

43. Deakin T, Whitham C: Structured patient education: the X-PERT Programme. Br J Community Nurs 2009, 14:398-404.

44. Deakin TA, Cade JE, Williams R, Greenwood DC: Structured patient education: the diabetes X-PERT Programme makes a difference. Diabet Med 2006, 23:944-954.

45. George JT, Valdovinos AP, Thow JC, Russell I, Dromgoole P, Lomax S, Torgerson DJ, Wells T: Brief Intervention in Type 1 diabetes - Education for Self-efficacy (BITES): Protocol for a randomised control trial to assess biophysical and psychological effectiveness. BMC Endocr Disord 2007, 7:6.

46. George JT, Valdovinos AP, Russell I, Dromgoole P, Lomax S, Torgerson DJ, Wells T, Thow JC: Clinical effectiveness of a brief educational intervention in Type 1 diabetes: results from the BITES (Brief Intervention in Type 1 diabetes, Education for Self-efficacy) trial. Diabet Med 2008, 25:1447-1453.

47. Armstrong N, Koteyko N, Powell J: 'Oh dear, should I really be saying that on here?': issues of identity and authority in an online diabetes community. Health (London) 2012, 16:347-365.
48. Armstrong N, Powell J: Preliminary test of an Internet-based diabetes self-management tool. J Telemed Telecare 2008, 14:114-116.

49. Jennings A, Powell J, Armstrong N, Sturt J, Dale J: A virtual clinic for diabetes self-management: pilot study. J Med Internet Res 2009, 11:e10.

50. Powell J, Jennings A, Armstrong N, Sturt J, Dale J: Pilot study of a virtual diabetes clinic: satisfaction and usability. J Telemed Telecare 2009, 15:150-152.

51. van der Ven NC, Lubach $\mathrm{CH}$, Hogenelst $\mathrm{MH}$, van Iperen $\mathrm{A}$, Tromp-Wever AM, Vriend A, van der Ploeg HM, Heine RJ, Snoek FJ: Cognitive behavioural group training (CBGT) for patients with type 1 diabetes in persistent poor glycaemic control: who do we reach? Patient Educ Couns 2005, 56:313-322.

52. Snoek FJ, van der Ven NC, Lubach CH, Chatrou M, Ader HJ, Heine RJ, Jacobson AM: Effects of cognitive behavioural group training (CBGT) in adult patients with poorly controlled insulin-dependent (type 1) diabetes: a pilot study. Patient Educ Couns 2001, 45:143-148.

53. van der Ven NC, Hogenelst MH, Tromp-Wever AM, Twisk JW, van der Ploeg HM, Heine RJ, Snoek FJ: Short-term effects of cognitive behavioural group training (CBGT) in adult Type 1 diabetes patients in prolonged poor glycaemic control. A randomized controlled trial. Diabet Med 2005, 22:1619-1623.

54. Schreurs KM, Colland VT, Kuijer RG, de Ridder DT, van Elderen T: Development, content, and process evaluation of a short selfmanagement intervention in patients with chronic diseases requiring self-care behaviours. Patient Educ Couns 2003, 51:133-141.

55. Roek MG, Welschen LM, Kostense PJ, Dekker JM, Snoek FJ, Nijpels G: Web-based guided insulin self-titration in patients with type 2 diabetes: the Di@log study. Design of a cluster randomised controlled trial [TC1316]. BMC Fam Pract 2009, 10:40.

56. Nijland N, van Gemert-Pijnen JE, Kelders SM, Brandenburg BJ, Seydel ER: Factors influencing the use of a Web-based application for supporting the self-care of patients with type 2 diabetes: a longitudinal study. J Med Internet Res 2011, 13:e71.

57. Heinrich E, de Nooijer J, Schaper NC, Schoonus-Spit MH, Janssen MA, de Vries NK: Evaluation of the web-based Diabetes Interactive Education Programme (DIEP) for patients with type 2 diabetes. Patient Educ Couns 2012, 86:172-178.

58. Rygg LO, Rise MB, Gronning K, Steinsbekk A: Efficacy of ongoing group based diabetes self-management education for patients with type 2 diabetes mellitus. A randomised controlled trial. Patient Educ Couns 2012, 86:98-105.

59. Rygg LO, Rise MB, Lomundal B, Solberg HS, Steinsbekk A: Reasons for participation in group-based type 2 diabetes self-management education. A qualitative study. Scand J Public Health 2010, 38:788-793.

60. Fico G, Fioravanti A, Arredondo MT, Leuteritz JP, Guillen A, Fernandez D: A user centered design approach for patient interfaces to a diabetes IT platform. Conf Proc IEEE Eng Med Biol Soc 2011, 2011:1169-1172.

61. Fioravanti A, Fico G, Arredondo MT, Leuteritz JP: A mobile feedback system for integrated E-health platforms to improve self-care and compliance of diabetes mellitus patients. Conf Proc IEEE Eng Med Biol Soc 2011, 2011:3550-3553.

62. Healthcare Alliances: Transforming local care. Cowbridge: Brittani House; 2000.

63. Bury M, Pink D: The HSJ debate. Self-management of chronic disease doesn't work. Health Serv J 2005, 115:18-19. 11

64. Lorig KR, Sobel DS, Stewart AL, Brown BW Jr, Bandura A, Ritter P, Gonzalez VM, Laurent DD, Holman HR: Evidence suggesting that a chronic disease self-management program can improve health status while reducing hospitalization: a randomized trial. Med Care 1999, 37:5-14.

65. Sturt J, Hearnshaw H, Barlow J, Hainsworth J: Supporting a curriculum for delivering Type 2 diabetes patient self-management education: a patient-needs assessment. Prim Health Care Res Dev 2005, 6:291-299.

66. Diabetes Education and Self-Management for Ongoing and Diagnosed. [http://www.desmond-project.org.uk/index.php]

67. Donald A: Birmingham Own Health - Agenda Item 4.4. In Book Birmingham Own Health - Agenda Item 4.4; 2009:1-5. (Editor ed.^eds.). pp. 1-5. City.

68. Georga E, Protopappas V, Guillen A, Fico G, Ardigo D, Arredondo MT, Exarchos TP, Polyzos D, Fotiadis DI: Data mining for blood glucose prediction and knowledge discovery in diabetic patients: the METABO diabetes modeling and management system. Conf Proc IEEE Eng Med Biol Soc 2009, 2009:5633-5636. 
69. Newman S, Steed L, Mulligan K: Self-management interventions for chronic illness. Lancet 2004, 364:1523-1537.

70. Shaya FT, Chirikov W, Howard D, Foster C, Costas J, Snitker S, Frimpter J, Kucharski K: Effect of social networks intervention in type 2 diabetes: a partial randomised study. J Epidemiol Community Health 2013, 68:326-332.

71. Kirk AF, Higgins LA, Hughes AR, Fisher BM, Mutrie N, Hillis S, Maclntyre PD: A randomized, controlled trial to study the effect of exercise consultation on the promotion of physical activity in people with Type 2 diabetes: a pilot study. Diabet Med 2001, 18:877-882.

72. Zinken KM, Cradock S, Skinner TC: Analysis System for Self-Efficacy Training (ASSET). Assessing treatment fidelity of self-management interventions. Patient Educ Couns 2008, 72:186-193.

73. Knight KM, Dornan T, Bundy C: The diabetes educator: trying hard, but must concentrate more on behaviour. Diabet Med 2006, 23:485-501.

74. Gomersall T, Madhill A, Summers LKM: A metasynthesis of the self-management of type 2 diabetes. Qual Health Res 2011, 21:853-871.

75. Lawton J, Ahmad N, Peel E, Hallowell N: Contextualizing accounts of illness: notions of responsibility and blame in white and South Asian respondents' accounts of diabetes causation. Sociol Health IIIness 2007 29:891-906

76. Furler J, Walker C, Blackberry I, Dunning T, Sulamain N, Dunbar J, Young $D$ : The emotional context of self-management in chronic illness: $A$ qualitative study of the role of health professional support in the self-management of type 2 diabetes. BMC Health Serv Res 2008, 8:214-223.

77. Zavras D, Tsiantou V, Pavi E, Mylona K, Kyriopoulos J: Impact of economic crisis and other demographic and socio-economic factors on self-rated health in Greece. Eur J Public Health 2013, 23:206-210.

78. O'Brien R, Wyke S, Guthrie B, Watt G, Mercer S: An 'endless struggle': a qualitative study of general practitioners' and practice nurses' experiences of managing multimorbidity in socio-economically deprived areas of Scotland. Chronic IIIn 2011, 7:45-59.

79. Jakab Z, Marmot M: Social determinants of health in Europe. Lancet 2012, 379:103-105.

80. Marmot M, Allen J, Bell R, Bloomer E, Goldblatt P: WHO European review of social determinants of health and the health divide. Lancet 2012, 380:1011-1029.

81. Protheroe J, Brooks H, Chew-Graham C, Gardner C, Rogers A: 'Permission to participate?' A qualitative study of participation in patients from differing socio-economic backgrounds. J Health Psychol 2012, 18:1-10.

82. Tsiligianni I, Anastasiou F, Antonopoulou M, Chliveros K, Dimitrakopoulos S, Duijker G, Kounalakis D, Makri K, Petraki C, Prokopiadou D, Tsiligianni I, Anastasiou F, Antonopoulou M, Chliveros K, Dimitrakopoulos S, Duijker G Kounalakis D, Makri K, Petraki C, Prokopiadou D, Stefanaki I, Symvoulakis E, Tsakountakis N, Vasilopoulos T, Vittorakis C, Lionis C, Cretan Practice based Primary Care Research Network 'G. Lambrakis', Clinic of Social and Family Medicine, School of Medicine, University of Crete: Greek rural GPs' opinions on how financial crisis influences health, quality of care and health equity. Rural Remote Health 2013, 13:2528.

83. UK Healthcare Commission Report: Managing Diabetes - Improving Services for People with Diabetes. In Book Managing Diabetes - Improving Services for People with Diabetes; 2007. (Editor ed.^eds.). City.

84. Department of Health: National Service Framework for Diabetes: Delivery Strategy. London: Department of Health; 2002.

85. Dallosso HM, Eborall HC, Daly H, Martin-Stacey L, Speight J, Realf K, Carey ME, Campbell MJ, Dixon S, Khunti K, Davies MJ, Heller S: Does self monitoring of blood glucose as opposed to urinalysis provide additional benefit in patients newly diagnosed with type 2 diabetes receiving structured education? The DESMOND SMBG randomised controlled trial protocol. BMC Fam Pract 2012, 13:18.

86. Ronda G, Portegijs P, Dinant GJ, Buntinx F, Norg R, van der Weijden T: Use of diagnostic self-tests on body materials among Internet users in the Netherlands: prevalence and correlates of use. BMC Public Health 2009, 9:100.

87. Arsand E, Tatara N, Ostengen G, Hartvigsen G: Mobile phone-based self-management tools for type 2 diabetes: the few touch application. J Diabetes Sci Technol 2010, 4:328-336.

88. Burkow TM, Vognild LK, Krogstad T, Borch N, Ostengen G, Bratvold A, Risberg MJ: An easy to use and affordable home-based personal eHealth system for chronic disease management based on free open source software. Stud Health Technol Inform 2008, 136:83-88.
89. Karlsen B, Idsoe T, Dirdal I, Rokne Hanestad B, Bru E: Effects of a group-based counselling programme on diabetes-related stress, coping, psychological well-being and metabolic control in adults with type 1 or type 2 diabetes. Patient Educ Couns 2004, 53:299-308.

90. Cooper H, Cooper J, Milton B: Technology-based approaches to patient education for young people living with diabetes: a systematic literature review. Pediatr Diabetes 2009, 10:474-483.

91. Vest BM, Kahn LS, Danzo A, Tumiel-Berhalter L, Schuster RC, Karl R, Taylor R, Glaser K, Danakas A, Fox CH: Diabetes self-management in a low-income population: impacts of social support and relationships with the health care system. Chronic Illn 2013, 9:145-155.

92. Dimova A, Rohova M, Moutafova E, Atanasova E, Koeva S, Pantelli D, van Ginneken E: Bulgaria health system review. Health Syst Transit 2012, 14:1-186.

93. Belsey JD, Pittard JB, Rao S, Urdahl H, Jameson K, Dixon T: Self blood glucose monitoring in type 2 diabetes. A financial impact analysis based on UK primary care. Int J Clin Pract 2009, 63:439-448.

94. Waller A, Franklin V, Pagliari C, Greene S: Participatory design of a text message scheduling system to support young people with diabetes. Health Informatics J 2006, 12:304-318.

95. Ritholz MD, Beverly EA, Weinger K: Digging Deeper: The Role of Qualitative Research in Behavioural Diabetes. Curr Diab Rep 2011, 11:494-502.

96. Peytremann-Bridevaux I, Lauvergeon S, Mettler D, Burnand B: Diabetes care: Opinions, needs and proposed solutions of Swiss patients and healthcare professionals: a qualitative study. Diabetes Res Clin Pract 2012, 97:242-250.

97. Lawton J, Peel E, Parry O, Araoz G, Douglas M: Lay perception of type 2 diabetes in Scotland: bringing health services back in. Soc Sci Med 2005, 60:1423-1435.

98. Moser A, van der Bruggen H, Widdershoven G: Competency in shaping one's life: autonomy of people with type 2 diabetes mellitus in a nurse-led, shared-care setting; a qualitative study. Int J Nurs Stud 2006, 43:417-427.

99. Moser A, van der Bruggen H, Widdershoven G, Spreeuwenberg C: Selfmanagement of type 2 diabetes mellitus: a qualitative investigation from the perspective of participants in a nurse-led, shared-care programme in the Netherlands. BMC Public Health 2008, 8:91.

100. Markaki A, Antonakis N, Philalithis A, Lionis C: Primary health care nursing staff in Crete: an emerging profile. Int Nurs Rev 2006, 53:16-18.

101. Blakeman T, Macdonald W, Bower P, Garwly C, Chew-Graham C: A qualitative study of GPs' attitudes to self-management of chronic disease. $\mathrm{Br} J \mathrm{Gen}$ Pract 2006, 56:407-414.

102. Wens J, Vermeire E, Royen PV, Sabbe B, Denekens J: GP's perspectives of type 2 diabetes patients' adherence to treatment: A qualitative analysis of barriers and solutions. BMC Fam Pract 2005, 6:20.

103. Blickem C, Bower P, Protheroe J, Kennedy A, Vassilev I, Sanders C, Kirk S, Chew-Graham C, Rogers A: The role of information in supporting self-care in vascular conditions: a conceptual and empirical review. Health Soc Care Community 2011, 19:449-459.

104. Gregory J, Robling M, Bennert K, Channon S, Cohen D, Crowne E, Hambly H, Hawthorne K, Hood K, Longo M, Gregory J, Robling M, Bennert K, Channon S, Cohen D, Crowne E, Hambly H, Hawthorne K, Hood K, Longo M, Lowes L, McNamara R, Pickles T, Playle R, Rollnick S, Thomas-Jones E: Development and evaluation by a cluster randomised trial of a psychosocial intervention in children and teenagers experiencing diabetes: the DEPICTED study. Health Technol Assess 2011, 15:1-202.

105. Avery L, Flynn D, van Wersch A, Sniehotta FF, Trenell Ml: Changing physical activity behavior in type 2 diabetes: a systematic review and meta-analysis of behavioral interventions. Diabetes Care 2012, 35:2681-2689.

106. Kousoulis AA, Symvoulakis EK, Lionis C: What Greece can learn from UK primary care experience and empirical research. Br J Gen Pract 2012, 62:543.

107. Scott KW, Powles J, Thomas H, Rechel B: Perceived barriers to the development of modern public health in Bulgaria: a qualitative study. Int J Public Health 2011, 56:191-199.

108. van Ginneken E, Groenewegen PP, McKee M: Personal healthcare budgets: what can England learn from the Netherlands? BMJ 2012, 344:e1383.

109. Walzer S, Nuijten M, Wiesner C, Kaier K, Johansson PO, Oertel S: Microeconomic surplus in health care: applied economic theory in health care in four European countries. Front Pharmacol 2013, 4:17.

110. van Dijk-de VA, Moser A, Mertens V-C, van der Linden J, van der Veijden T, van Eijk TM: The ideal of biopsychosocial chronic care: How to make it real? A qualitative study among Dutch stakeholders. BMC Fam Pract 2012, $13: 14$. 
111. Gately C, Rogers A, Sanders C: Re-thinking relationship between long-term condition self-management education and the utilisation of health services. Soc Sci Med 2007, 65:934-945.

112. Mathew R, Gucciardi E, De Melo M, Barata P: Self-management experiences among men and women with type 2 diabetes mellitus: a qualitative analysis. BMC Fam Pract 2012, 13:122.

113. Miller TA, Dimatteo MR: Importance of family/social support and impact on adherence to diabetic therapy. Diabetes Metab Syndr Obes 2013, 6:421-426.

114. Oftedal B, Karlsen B, Bru E: Perceived support from healthcare practitioners among adults with type 2 diabetes. J Adv Nurs 2010, 66:1500-1509.

doi:10.1186/1472-6963-14-453

Cite this article as: Kousoulis et al: Diabetes self-management arrangements in Europe: a realist review to facilitate a project implemented in six countries. BMC Health Services Research 2014 14:453.

\section{Submit your next manuscript to BioMed Central and take full advantage of:}

- Convenient online submission

- Thorough peer review

- No space constraints or color figure charges

- Immediate publication on acceptance

- Inclusion in PubMed, CAS, Scopus and Google Scholar

- Research which is freely available for redistribution 